\title{
Morphology and wall ultrastructure of leiosphaeric and acanthomorphic acritarchs from the Ediacaran of Australia
}

\author{
S. WILLMAN \\ Uppsala University, Department of Earth Sciences, Palaeobiology, Villavägen 16, SE-752 36, Uppsala, Sweden
}

\begin{abstract}
Acritarchs are a group of organic-walled microfossils with unknown biological affinities. The wall ultrastructure of the unornamented, smooth Leiosphaeridia sp. and the acanthomorphic Gyalosphaeridium pulchrum from the Ediacaran Dey Dey Mudstone in the Officer Basin, South Australia, was studied by use of transmission and scanning electron microscopy, and transmitted light microscopy. The study of the ultrastructure reveals a complexity in the cell wall not seen in prokaryotes. Wall ultrastructures range from single-layered to three- or four-layered and from homogeneous to porous. Acritarchs with different wall ultrastructures may be different organisms, but may also reflect different stages in a life cycle. In this paper I review previous ultrastructure studies and discuss possible algal and metazoan affinities for the specimens studied herein.
\end{abstract}

Received 5 September 2008; accepted 13 October 2008

Corresponding author: Sebastian Willman. Tel.: +46184712742; fax: +461847125 92; e-mail: sebastian.willman@geo.uu.se

\section{INTRODUCTION}

The informal group Acritarcha (Evitt, 1963) includes a variety of geographically widespread organic-walled microfossils, mostly of unknown biological affinities, that are common components of the rock record from the Palaeoproterozoic to Recent. Acritarchs are polyphyletic and are thought to represent a variety of phylogenetically distant organisms. Possible biological affinities have been recognized in a few particular taxa by means of specific morphological characters, the ultrastructure of the cell wall or inferred through biochemical signatures assumed to be taxon specific.

Based on overall vesicle morphology, excystment structures, and palaeoecological distribution, most acritarchs are generally inferred to be the resting cysts of marine phytoplankton (e.g. Tappan, 1980; Colbath \& Grenfell, 1995; Strother, 1996). Based on molecular (Moldowan et al., 1996; Moldowan \& Talyzina, 1998) and morphological (Butterfield \& Rainbird, 1998; Meng et al., 2005) evidence, some Proterozoic acritarchs have been suggested to be dinoflagellates or, at least, stem group dinoflagellates. Biological affinities to fungi (Butterfield, 2005a) and red algae (Butterfield, 2000) have been proposed for other specimens of Proterozoic acritarchs. Van Waveren \& Marcus (1993) brought to attention the morphological similarities between recent copepod egg capsules (or egg hulls, egg cases, egg shells) and acritarchs. It is thus likely that the morphology of many acritarchs is broadly shared among several different phyla, probably including both prokaryotes and eukaryotes, and hence gross morphology cannot be used on its own as a distinguishing factor.

Acritarch assemblages change significantly through time in terms of morphology and size, particularly during the Ediacaran Period. Acritarchs are, in general, large during the Ediacaran, before diminishing in size in the Phanerozoic (Huntley et al., 2006). Differences between Proterozoic and Phanerozoic assemblages have suggested to some researchers that many Ediacaran acritarchs represent benthic and even heterotrophic life stages, whereas the smaller Phanerozoic examples are planktonic and photosynthetic (Butterfield, 2005a,b; Knoll et al., 2006a). An example of this train of thought is the recent interpretation of the Ediacaran-age acritarch Tianzhushania from South China as the egg capsules of an unspecified metazoan (Yin et al., 2004; Yin et al., 2007). Embryo-containing Tianzhushania is thus far only found in the upper part of the Doushantuo Formation but the form-taxon is present just above an ash layer dated at $632.5 \pm 0.5 \mathrm{Ma}$ (Condon et al., 2005). If the interpretation that all Tianzhushania are of animal origin is accepted, it suggests that other large acanthomorphic microfossils may also be remains of early animals.

In recent years, different microscopic and geochemical methods have been used to study the biological affinities of acritarchs (e.g. Javaux \& Marshal, 2006; Knoll et al., 2007). Ultrastructure studies on Palaeozoic microfossils by use of transmission electron microscopy (TEM) was initiated in the 1960s and continued with studies on Proterozoic acritarchs (Wall, 1962; Jux, 1968, 1969a,b, 1971; Kjellström, 1968;

(C) 2008 The Author Journal compilation @ 2008 Blackwell Publishing Ltd 
Martin \& Kjellström, 1973; Peat, 1981). Previous results indicated that certain species of the genera Leiosphaeridia and Tasmanites are related to green algae, particularly prasinophytes and chlorophytes. Work by Talyzina \& Moczydłowska (2000) on lower Cambrian acritarchs (including both leiospheres and acanthomorphs) revealed four different types of wall ultrastructure ranging from single-layered to multilayered and from homogeneous to fibrous. Of particular interest to this study is that their specimens of Leiosphaeridia spp. showed affinities to green algae (order Chlorococcales) based on a multilayered wall ultrastructure with a preserved trilaminar sheath structure (TLS; diagnostic of some green algae, Brunner \& Honegger, 1985). They also suggested that their specimens of Tasmanites tenellus belonged to the prasinophytes, based on a homogeneous and electron-dense wall ultrastructure perforated by pore canals.

Examination of the wall ultrastructure of some Proterozoic acritarchs including, again, both leiospheres and acanthomorphs, combined with geochemical analyses has suggested phylogenetic relationships of some acritarchs to dinoflagellates and/or chlorophyceans (Arouri et al., 1999, 2000; Talyzina, 2000; Javaux et al., 2004; Marshall et al., 2005, 2006). TEM analysis of Mesoproterozoic acritarchs from the Roper Group in Australia and the Ruyang Group in China ( 1.5-1.4 Ga) prompted Javaux et al. (2004) to suggest eukaryotic affinities of morphologically simple leiospheres, a conclusion that is difficult to make based on morphology alone. Recently, Willman \& Moczydłowska (2007) described a complex fourlayered wall ultrastructure from Ediacaran age Gyalosphaeridium pulchrum from the Officer Basin in Australia and suggested that the specimen could represent the resting cyst stage of a green alga.

Here, I describe the wall ultrastructure of additional specimens of Leiosphaeridia and Gyalosphaeridium from the Officer Basin, and discuss their possible relationship to algae and metazoans.

\section{MATERIALS AND METHODS}

The acritarchs were recovered from the Dey Dey Mudstone in the Murnaroo 1 borehole (at $230.4 \mathrm{~m}$ depth), located in the eastern Officer Basin $\left(29^{\circ} 01^{\prime} 25^{\prime \prime} \mathrm{S}, 132^{\circ} 01^{\prime} 35^{\prime \prime} \mathrm{E}\right)$ in South Australia (Fig. 1A). The Dey Dey Mudstone is a green mudstone that was probably deposited under open-marine conditions on the platform/shelf (Fig. 1B; Zang, 1995). The sediments are structurally undeformed, and have experienced low thermal alteration. There are no direct age constraints on the succession but the relative position of the Dey Dey Mudstone, and its equivalents in the Adelaide Rift Complex, to the underlying Elatina Formation (Grey, 2005; Knoll et al., 2006b; Grey \& Calver 2007) and the Acraman impact ejecta layer (Hill et al., 2004, 2007) gives a lower-middle Ediacaran age of the succession studied here (Fig. 1C). The base of the Ediacaran Period is defined as the base of the Nuccaleena Formation, a cap carbonate overlying the Elatina Formation
('Marinoan' diamictite equivalent) in the Adelaide Rift Complex (Knoll et al., 2006b). The Nuccaleena Formation is commonly inferred to correlate with the cap carbonate at the base of the Doushantuo Formation of China dated at $c$. $635 \mathrm{Ma}$ (Condon et al., 2005) but could be younger than this if the Elatina Formation is correlated to younger glaciogenic rocks in Tasmania and King Island (Calver et al., 2004). Being preserved in shale, the organic-walled microfossils have experienced substantial flattening and although this has introduced folding and mechanical breakage of the acritarchs they are well preserved. The rock samples were processed using the maceration technique described by Grey (1999). For further information on geological setting, palaeoenvironment, thermal alteration and the taxonomy see Willman et al. (2006).

For this study six specimens of Leiosphaeridia sp. and six specimens of Gyalosphaeridium pulchrum were prepared for TEM. The preparation followed a standard protocol in which the specimens were washed repeatedly in a buffer solution and fixated for $\mathrm{l} \mathrm{h}$ in $1 \%$ osmium tetroxide $\left(\mathrm{OsO}_{4}\right)$. After fixation the sample was again repeatedly washed in buffer solution and stepwise dehydrated in ethanol (20\% steps up to $100 \%)$ followed by acetone. After dehydration, the microfossils were infiltrated in a mixture of TAAB 812 epoxy resin and acetone in equal proportions, left overnight and embedded in silicon plates. The plates were then left to polymerize at $50{ }^{\circ} \mathrm{C}$ for $48 \mathrm{~h}$. Serial sections were cut into slices $50 \mathrm{~nm}$ thick using an LKB Ultramicrotome (Diversified Equipment Lorton, VA, USA), and analysed using a Zeiss Supra 35VP microscope (Zeiss, Germany). The collection of TEM sections and SEM stubs are currently stored at Uppsala University, Sweden.

\section{FOSSIL DESCRIPTIONS}

\section{Observations by use of transmitted light microscopy}

The Leiosphaeridia specimens are morphologically simple, spherical, unornamented vesicles lacking excystment structures, and with vesicle diameters ranging from 150 to $400 \mu \mathrm{m}$ $(N=6)$ (Fig. 2A). Because of the lack of diagnostic features it is here referred to as Leiosphaeridia sp., without specific identification; however, all specimens studied here have thick walls (some affected by pyrite framboid formation during degradation), and would fit in Leiosphaeridia jacutica if an assignment is necessary.

The other morphotype is described as Gyalosphaeridium pulchrum and it has a circular to subcircular vesicle outline, probably originally spheroidal, covered with numerous hollow processes that are closely spaced but discrete. Processes are predominantly cylindrical with slightly widened conical bases, and tapering, with acuminate or blunt tips. Processes are open into the vesicle cavity and no excystment structure was observed (Fig. 2B). The dimensions of the specimens prepared and sectioned for TEM are: vesicle diameter $c .350-450 \mu \mathrm{m}$, process length 10-30 $\mu \mathrm{m}$, and process basal width 5-15 $\mu \mathrm{m}(N=6)$. 


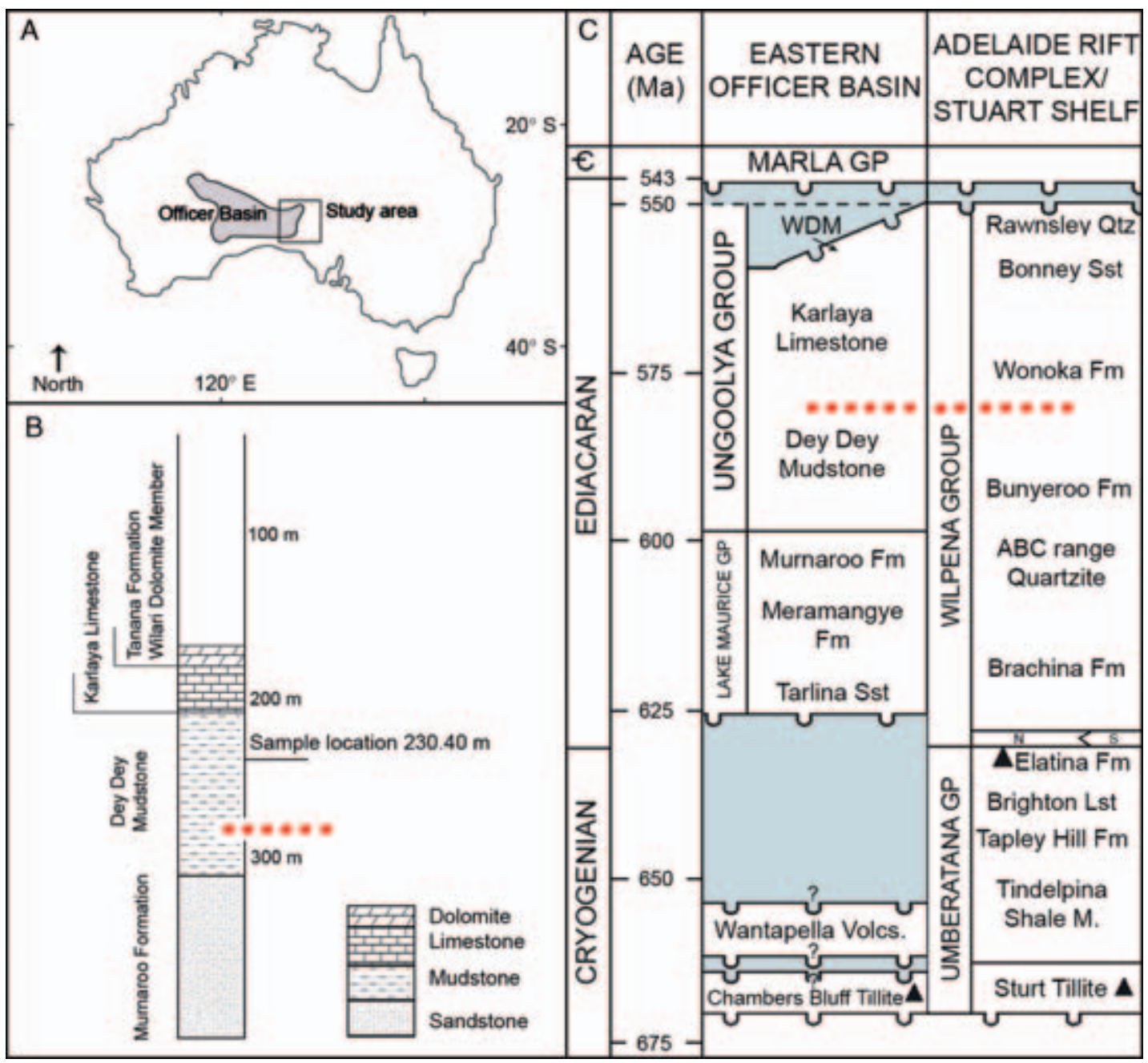

Fig. 1 (A) Map of Australia showing the location of the Officer Basin and the study area in Eastern Officer Basin. (B) Lithostratigraphic column of Murnaroo 1 drillhole, showing the level of the sample in the Dey Dey Mudstone and the location of the Acraman impact ejecta layer at $279.55 \mathrm{~m}$ (Hill et al., 2004). (C) Selected stratigraphic units from the Eastern Officer Basin and its correlation to the Adelaide Rift Complex/Stuart Shelf. Note the position of the Acraman impact ejecta layer that is found in the Dey Dey Mudstone in the Officer Basin and in the Bunyeroo Fm in the Adelaide Rift Complex/Stuart Shelf. $N=$ Nuccaleena Fm which is the start of the Ediacaran Period is here assumed to be $\sim 635$ Ma. C = Cambrian; WDM = Wilari Dolomite Member; $S=$ Seacliff Sst.

\section{Observations on Leiosphaeridia sp. by use of TEM}

Ultrathin sections of one specimen of Leiosphaeridia sp. (Fig. 3) show a three, possibly four-layered, cell wall with an overall thickness of $250-850 \mathrm{~nm}(0.25-0.85 \mu \mathrm{m})$. From the external to the internal the layers are here described as Layers A-D. The external layer (Layer A) is dark, electron-dense, uniform and homogeneous with a thickness that varies between $140-200 \mathrm{~nm}$. It responded plastically to deformation (i.e. it did not fracture during fossilization or preparation). The second layer (Layer B) is light, electronlucent and porous, and is more irregular in its thickness, varying between $140-280 \mathrm{~nm}$. In one part of the vesicle, Layer B forms a structure that is probably pustular in three dimensions (Fig. 3E). The innermost layer (Layer C) is electron-dense but lighter than Layer A. It is the thickest layer of the three, measuring up to $420 \mathrm{~nm}$. Layer $\mathrm{C}$ seems to consist of distinct units that are separated from each other at irregular intervals, probably representing punctae, or pits (Fig. 3A-C). In addition to the three clearly discernible layers, there is a fourth innermost layer (Layer D) that is only partially preserved. It is light, electron-lucent and $c .50 \mathrm{~nm}$ thick; it is most easily seen where it detaches from Layer C (Fig. 3F,G).

A number of globular structures can be seen on the inside of the vesicle cavity of this Leiosphaeridia specimen. The globules vary in size $(10-300 \mathrm{~nm})$, and are light grey to dark grey. The globules are always located close to the inner vesicle wall with the exception of Fig. 3(F,G), where the globules appear also outside the vesicle. However, this part is broken and the 


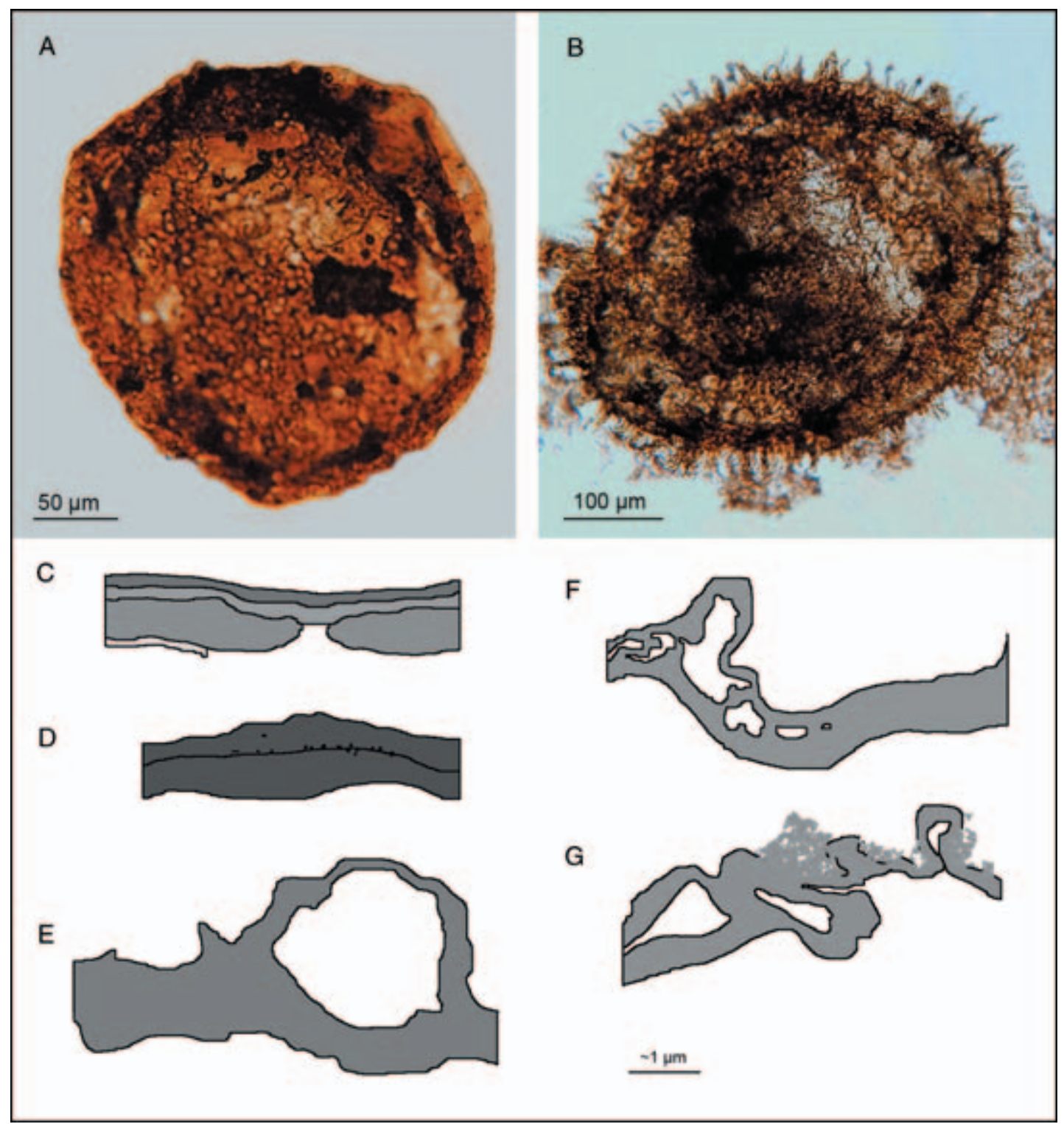

Fig. 2 Representatives of Leiosphaeridia sp. (A) and Gyalosphaeridium pulchrum (B) from the Ediacaran of the Officer Basin, Australia, and a schematic drawing of different wall ultrastructures described herein (C-G). (A-B) are both from the Dey Dey Mudstone (A) 230.40 m3-B/13 and (B) 230.40 m3-L/18/4. For further explanations, see the text. Drawings are not exactly to scale. (A) Leiosphaeridia sp., many specimens have a 'pitted-like' structure on the surface, perhaps corresponding to the perforation in layer C (see Fig. 3C). (B) G. pulchrum, displaying tapering processes. (C) Schematic drawing of Leiosphaeridia sp. showing three distinct layers and a rarely preserved fourth layer. (D) Schematic drawing of Leiosphaeridia sp. showing two layers separated by organic matter. (E) Schematic drawing of Leiosphaeridia sp. showing a single-layered ultrastructure. (F) Schematic drawing of G. pulchrum, showing a single-layered ultrastructure. (G) Schematic drawing of G. pulchrum, showing a single-layered ultrastructure with irregular outer surface.

vesicle wall may have been folded around the globules. The nature and appearance of the globules suggest that they are preserved internal structures rather than taphonomic or procedural artefacts.

Three other specimens of Leiosphaeridia sp. (Fig. 4A-C) have slightly different wall ultrastructures. The first (Fig. 4A) shows a single-layered, homogeneous wall that is $0.56-1.8 \mu \mathrm{m}$ in thickness. A rounded void, formed as a cavity in the otherwise homogeneous layer, is a character that is also seen in G. pulchrum (arrow in Fig. 4F). The two other specimens (Fig. 4B,C) show a two-layered ultrastructure in which the layers, even though similar in electron density, are differentiated by the particulate organic matter wedged between the two layers (arrow in Fig. 4B). When the two walls collapse they are superimposed on each other, which, if not recognized as a collapse structure, may be misinterpreted as a multilayered structure (box in Fig. 4B,C). The overall wall thickness in these specimens is $0.2-0.75 \mu \mathrm{m}$. 
A
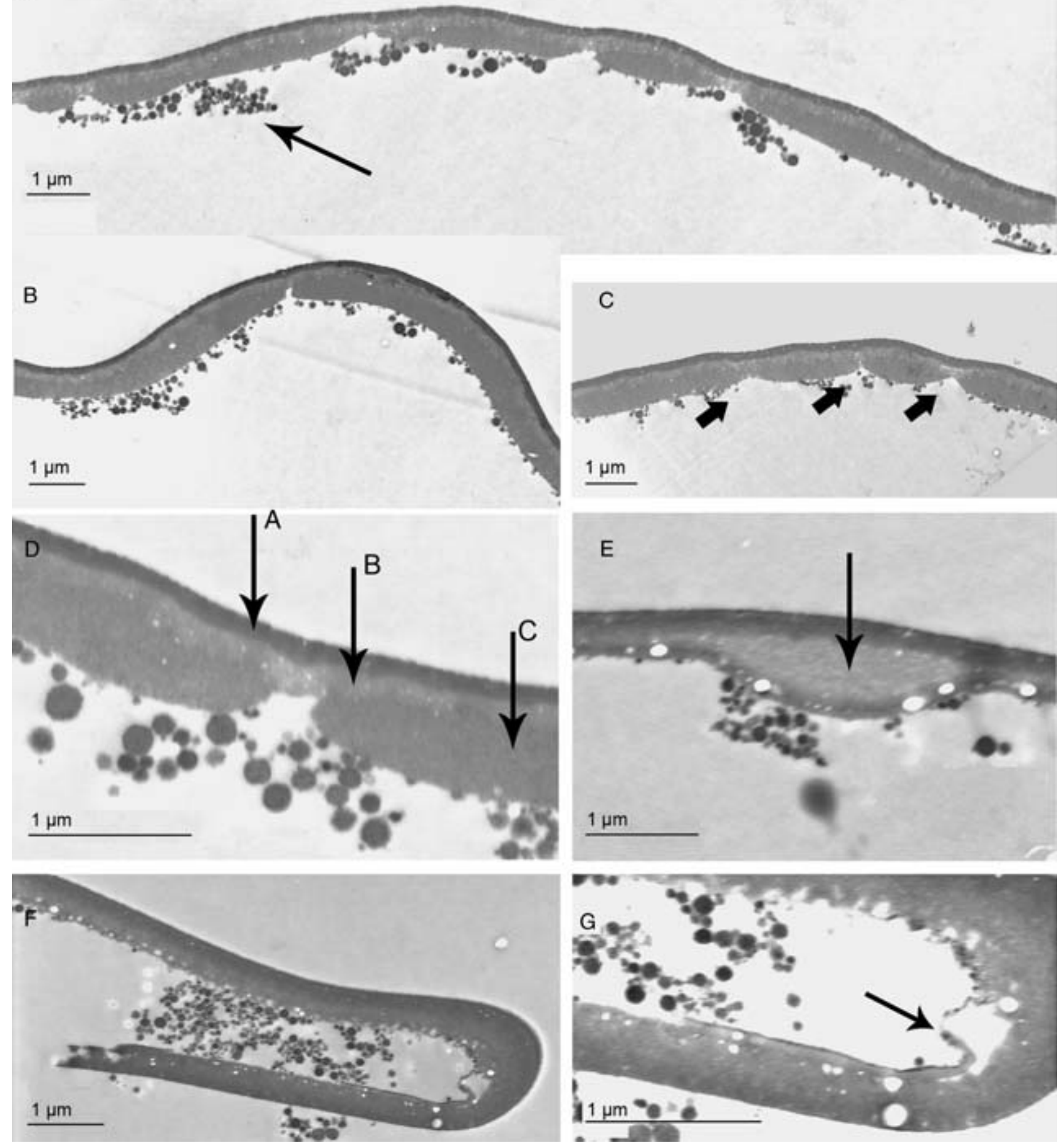

Fig. 3 Transmission electron microscopy micrographs of the wall ultrastructure of Leiosphaeridia sp. from the Ediacaran of the Officer Basin, Australia. All figures are from the same specimen. (A) Cross-section through the entire vesicle wall, showing three discrete layers (A-C, in D). Arrow points at the globules that are present on the inner surface; specimen 12-A154. (B) Leiosphaeridia sp., showing gentle, ductile deformation; specimen 12-A151. (C) Leiosphaeridia sp., note how layer $C$ seems to consist of distinct units that are separated from each other at irregular intervals (arrowed); specimen 12-A165. (D) Leiosphaeridia sp., showing the three layers and the regular thinning of layer C. A is the external layer, B is the central (medial) layer and C the internal layer; specimen 12-A168. (E) Leiosphaeridia sp., note the pustular structure within layer B (arrowed); specimen 12-A152. (F) Leiosphaeridia sp., showing a broken part of the vesicle wall with partially disintegrated and detached internal layer; specimen 12-A166. (G) Leiosphaeridia sp., close-up of (F) displaying a detached, fourth, and rarely preserved inner layer; specimen 12-A167. 

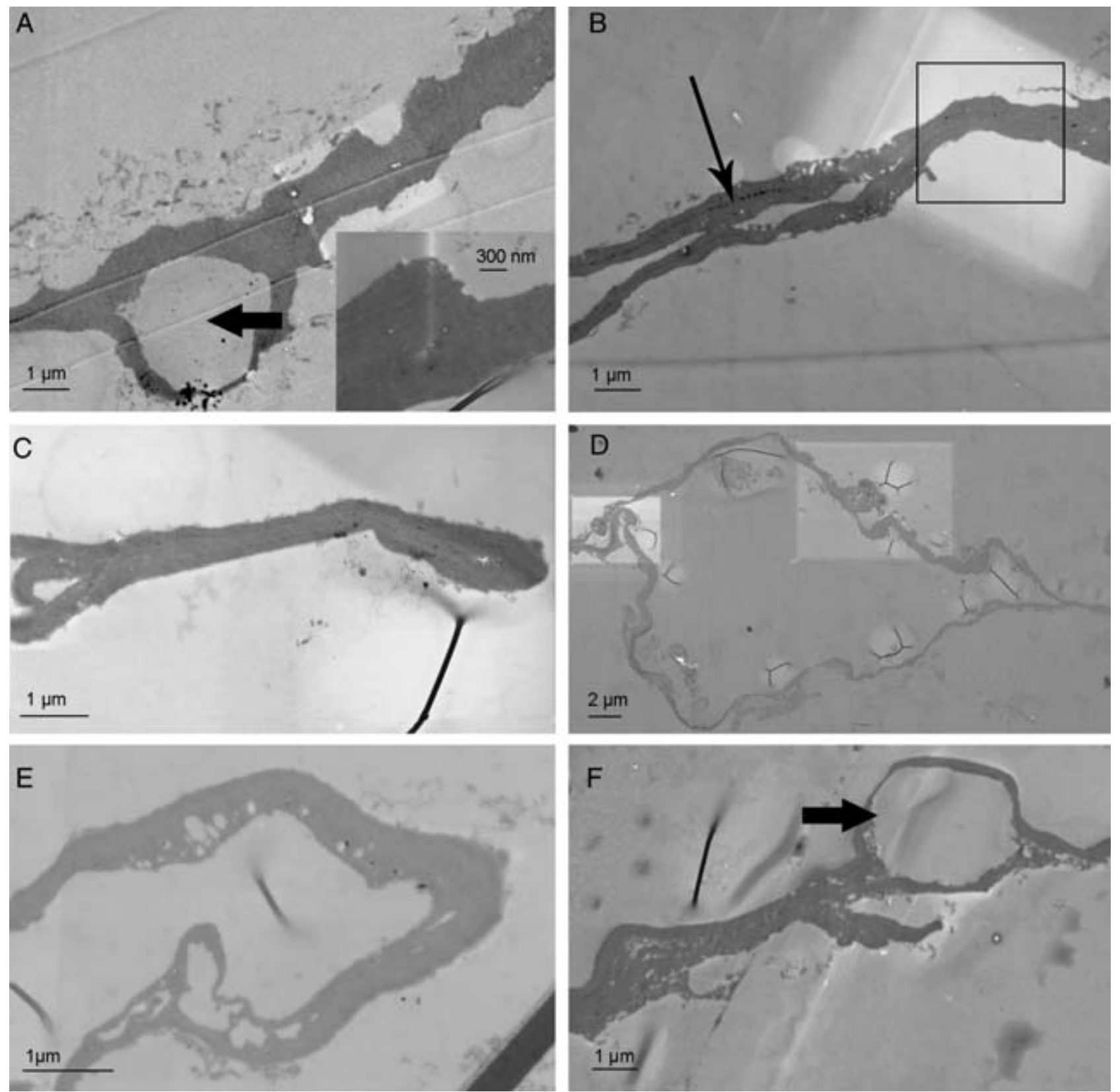

Fig. 4 Transmission electron microscopy micrographs showing comparable wall ultrastructures in leiosphaeric (Leiosphaeridia sp.; A-C) and acanthomorphic (G. pulchrum; D-F) acritarchs from the Ediacaran of the Officer Basin, Australia. (A) Leiosphaeridia sp., showing a homogeneous wall ultrastructure, with a rounded internal void (arrowed). Inset figure shows 'pseudo-lamellae' which are the result of the cutting of the specimen during preparation; specimen 3-A040. (B) Leiosphaeridia sp., showing a two-layered wall ultrastructure (arrowed) and the two walls superimposed on each other due to compaction (boxed); specimen 11-A137. (C) Leiosphaeridia sp., showing a two-layered wall ultrastructure that has been folded back on itself. The two layers are similar in optical appearance but the darker material separating the layers reveals its two-layered structure; specimen 9-A102. (D) G. pulchrum, cross-section through a large part of the vesicle wall; specimen 6-A044. (E) G. pulchrum, different part of the specimen in (D), note the alveolar inner part of the vesicle; specimen 6-A049. (F) G. pulchrum, different specimen, showing similar internal rounded void (arrowed) as displayed in Leiosphaeridia sp. (A); specimen 15-A175.

\section{Observations on Gyalosphaeridium pulchrum by use of SEM and TEM}

TEM sections of well-preserved G. pulchrum demonstrate a mainly single-layered wall ultrastructure (Figs 4D-F and 5).
Thickness of the vesicle wall varies between 0.7 and $1.5 \mu \mathrm{m}$. Most often the response to folding is by plastic deformation (arrow in Fig. 5C,D) and this wall plasticity is probably also the reason for the variation in layer thickness. Occasionally, though, deformation is brittle (box in Fig. 5E). Although the 

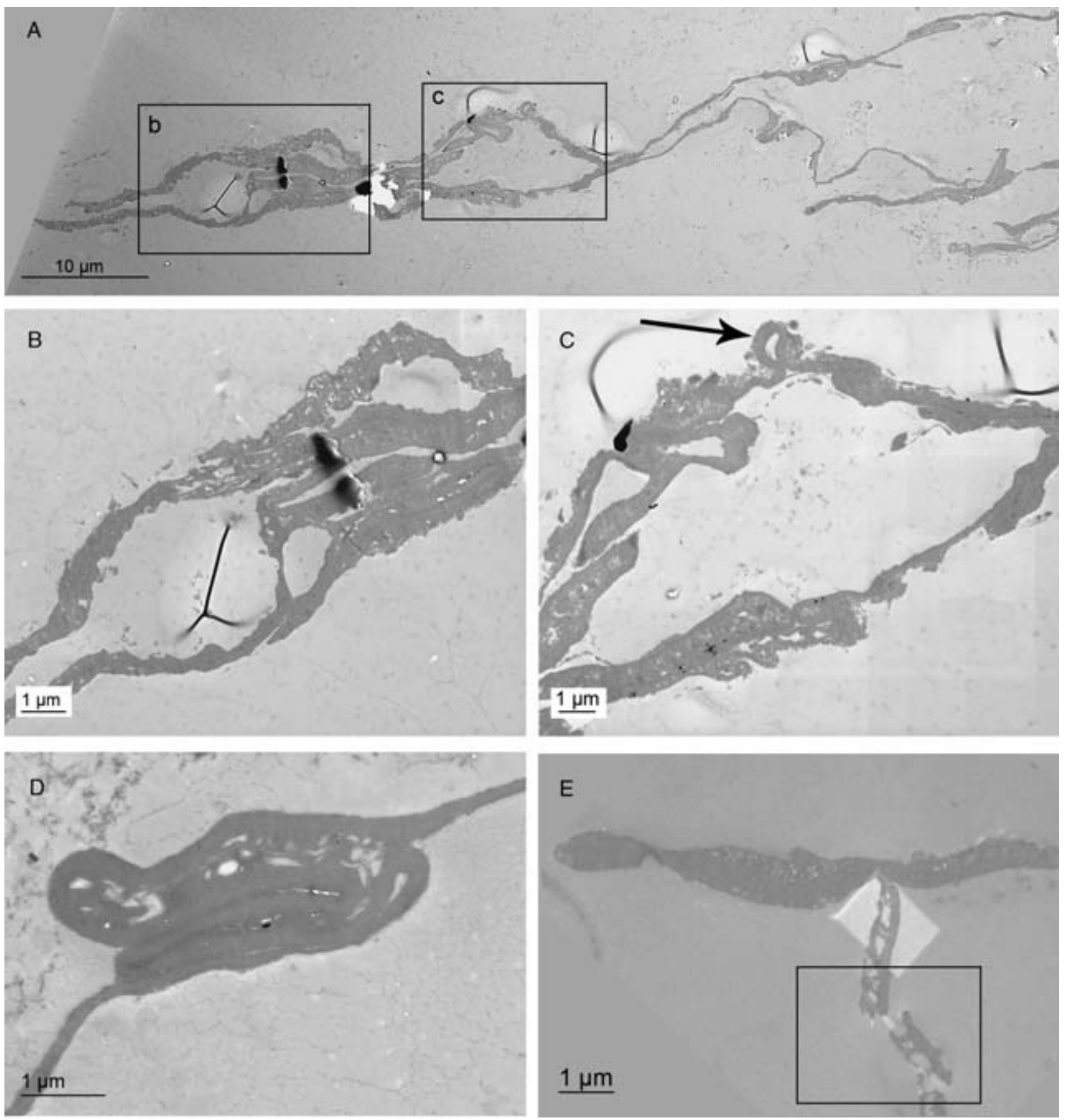

Fig. 5 Transmission electron microscopy micrographs of three different specimens of Gyalosphaeridium pulchrum from the Ediacaran of Officer Basin, Australia. (A) G. pulchrum, showing the major part of the vesicle wall at low magnification, black boxes are displayed at higher magnification in (B-C); specimen 10-A121. (B) G. pulchrum, showing the folded and compressed vesicle; specimen 10-A123. (C) G. pulchrum, showing ductile deformation of the vesicle wall (arrowed); specimen 10-A122. (D) G. pulchrum, showing the ductile deformation of the vesicle wall; specimen 15-A176. (E) G. pulchrum, showing brittle deformation of the vesicle wall which is probably a result of the preparation process; specimen 1-A019.

wall appears to be single-layered and mainly homogeneous, some parts of the wall are porous (Fig. 5B) and other parts are alveolar. This suggests that the cell wall is rather more complex.

\section{DISCUSSION}

Resolving acritarch affinities is important for understanding the evolution of late Proterozoic biosphere and its ecosystems, 
which in turn would have significant implications for our understanding of the evolution of biogeochemical cycling. In particular, if some acritarchs could be shown to be metazoan, then they would add a significant new source of data concerning the earliest evolution of this critical group (Butterfield, 2007).

Previous studies have shown that wall ultrastructures in Palaeozoic and Proterozoic acritarchs can vary from singlelayered to multilayered and from electron-lucent to electrondense. The layers can be homogeneous, fibrous, porous, amorphous or laminated. None of these features on their own are decisively indicative of biological affinities, although each in their turn offers a refinement of possible alternatives.

A large proportion of Proterozoic palynomorph assemblages are often comprised of unornamented leiospheres, and hundreds of species have been identified. Leiosphere taxa are often described using arbitrarily chosen parameters, like size and wall thickness, and distinguishing between species is difficult at best. It is likely that many of the seemingly similar acritarchs may in fact represent different types of organisms. TEM studies of the ultrastructure of some leiospheres have shown that they differ significantly from each other in terms of numbers of layers and types of cell walls. Talyzina \& Moczydłowska (2000) described a multilayered structure in Leiosphaeridia spp., whereas Arouri et al. (2000) found that their specimens of Chuaria circularis, Tasmanites sp. and Leiosphaeridia sp. were all single-layered. The absence of a TLS (see next section) in their specimens also prompted Arouri et al. (2000) to consider them unrelated to chlorophytes. Javaux et al. (2004) used TEM to assess whether or not Leiosphaeridia jacutica, Leiosphaeridia crassa and Leiosphaeridia tenuissima were of eukaryotic or prokaryotic origin instead of trying to link the leiospheres to a particular group of organisms. These specimens displayed a multilayered cell wall, and since such complex structures are unknown among prokaryotes, the authors concluded that they were eukaryotes.

\section{Are these acritarchs algae?}

It is generally assumed that many acritarchs represent algae in various life stages. It is, however, also clear that with a few exceptions, acritarchs cannot confidently be assigned to extant organisms. Algae encompass several distantly related groups of eukaryotic, aquatic, photosynthetic organisms that can be single- or multicellular. Despite the enormous diversity of modern algae, the fossil record is inevitably biased towards algal groups that have the potential to be preserved as fossils. Some algae are preserved as body fossils in the form of palynomorphs (e.g. acritarchs) or as biominerals (e.g. calcareous coccolithophores, or siliceous diatoms), others leave traces in the form of biochemical components such as lipids (e.g. Eustigmatophyta) (see Knoll et al., 2007 for a recent overview of primary producers through time). Looking at the diversity of modern algae, what character can we use to positively rather than tentatively identify organic-walled microfossils as algae?

As mentioned above, based on morphology a similarity between some acritarchs and various modern groups of algae is clear. Many Palaeozoic and Mesozoic fossils not only resemble, but also likely represent, phycomate prasinophytes related to extant Pachysphaera, Halosphaera and Pterosperma (Tappan, 1980; Colbath \& Grenfell, 1995). Representatives of green algae such as Prasinophyceae, Hydrodictyaceae, Zygnemataceae and Chlorophyceae probably extend far back into the Proterozoic (Knoll et al., 2006a). However, using gross morphology for taxonomic identification may not be reliable because of the general simplicity and the likelihood of convergence.

A membrane-like TLS has been used as a diagnostic feature of some green algae. The TLS is $10-20 \mathrm{~nm}$ thick and consists of two electron-dense sublayers sandwiching an electron-lucent sublayer (Brunner \& Honegger, 1985; Derenne et al., 1992a, 1996; Allard \& Templier 2000; Hagen et al., 2002). TLScontaining microalgae have also been reported to produce an insoluble, bacterially resistant, aliphatic biopolymer called algaenan (e.g. Derenne et al., 1992b, 1996; Gelin et al., 1999). Preserved TLS has been described from an acritarch from the Cambrian (Talyzina \& Moczydłowska, 2000) and possibly from the Neoproterozoic (Arouri et al., 1999) and Mesoproterozoic (Javaux et al., 2004), although the latter two are less convincing (poorly, or fragmentarily preserved, or with the wrong dimensions). Consequently, although presence of TLS is indicative of some green algae, there are many green algae in which TLS is absent and there is no relationship between presence of algaenan and presence of a TLS. Therefore, although presence of a TLS suggests a green algal affinity, absence of a TLS does not rule out such microalgal affinity.

The cell wall ultrastructure of Leiosphaeridia sp. revealed in the present study ranges from single-layered and homogeneous to two-, three- and possibly four-layered. These specimens are undoubtedly eukaryotic, since no known prokaryotic organisms are able to produce acid-resistant complex walls (sensu Javaux et al., 2004). Some prasinophyte green algae have a diagnostic ultrastructure consisting of a homogeneous and electron dense cell wall that is punctuated by pore canals (Jux, 1968). A similar perforated cell wall was described in Chuaria circularis from the Neoproterozoic (Jux, 1977; Amard, 1992) and Tasmanites tenellus from the Cambrian (Talyzina \& Moczydłowska, 2000), demonstrating a possible relationship to chlorophytes. A comparable but not identical structure, consisting of punctae, or pits, rather than perforations, is observed herein (Fig. 3A-D). These punctae do not, however, penetrate the outer layer and although similar to those of modern algae they may or may not indicate a prasinophyte relationship.

Hagen et al. (2002) described changes in wall ultrastructure of a unicellular volvocalean green alga (Haematococcus pluvialis) during the transformation of flagellates into aplanospores. They divided the process into separate phases: building of the 
primary wall; formation of TLS; and finally formation of the secondary wall. Damiani et al. (2006) studied the same taxon and discovered a third, thick, homogeneous and compact layer in the final, aplanospore stage. The thick wall that Damiani et al. (2006) described is similar to the most prominent layer in Leiosphaeridia sp. described herein as Layer C, which is homogeneous and electron-dense, and the equivalent single layer in G. pulchrum. If the acritarchs described here are green algae, then Layer $\mathrm{C}$ in Leiosphaeridia sp. is the protective layer that is the final stage in aplanospore formation (compare fig. 13 in Hagen et al., 2002). If this interpretation is correct, it can also explain why the same taxon has different wall ultrastructures because microfossils preserved at different stages in their life cycle will show different ultrastructures and number of wall layers. As an example, the wall in G. pulchrum described by Willman \& Moczydłowska (2007) consists of four discrete layers, whereas the specimens of G. pulchrum described herein have fewer layers. Following the reasoning above, the specimens described in this study are thus in the processes of forming an aplanospore, whereas the specimen of Willman \& Moczydłowska (2007) is more advanced in its development towards the final aplanospore stage.

\section{Possible metazoan affinities}

Ediacaran acritarchs are on average larger than their Phanerozoic counterparts (Huntley et al., 2006) and excystment structures are uncommon in Australian material (e.g. Grey, 2005; Willman et al., 2006; Willman \& Moczydłowska, 2008). Such observations have been used to argue that a benthic heterotrophic habit is more likely than a planktonic phototrophic habit for at least some acritarchs in the Proterozoic (Butterfield, 2005a,b; Knoll et al., 2006a). One example of a non-algal affinity is the study by Yin et al. (2004) in which they compared the phosphatized, ornamented, acritarch Megasphaera ornata with the silicified, acanthomorphic acritarch, Tianzhushania tuberifera. They concluded that these two morphologically different acritarchs actually represent the same taxon (Tianzhushania ornata comb. nov.) preserved by different mineralization processes in which $T$. tubifera has lost its original outer cover. Megasphaera ornata (and Megasphaera inornata) had previously been described as animal resting-eggs and blastulas (Xiao et al., 1998; Xiao \& Knoll, 2000), and Yin et al. (2004) described a possible two-cell cleavage in Tianzhushania sp. Consequently, an animal affinity was inferred for the Tianzhushania taxon. More recently, Yin et al. (2007) discovered 1-, 2-, 4-, 8- and 16-cell stages in phosphatized Tianzhushania spinosa from the Doushantuo Formation in South China, confirming the hypothesis that some morphologically complex acritarch vesicles represent a stage in a metazoan life cycle. Embryocontaining Tianzhushania are only known from the upper part of the Doushantuo Fm but the appearance of the same formtaxon close to the Nantuo glaciation, just above an ash-layer dated at $632.5 \pm 0.5 \mathrm{Ma}$ (Condon et al., 2005), in theory pushes the earliest record of metazoans back to this date, predating the classic soft-bodied Ediacara-type fauna by c. $60 \mathrm{Ma}$. Although the early record of animals is still scarce and debated (e.g. Budd, 2008), such an early age for an animal fossil is not implausible. However, the fact that large morphologically complex acritarchs may have animal affinities suggests that comparison of the ultrastructure of equally large, complex Ediacaran acritarchs to modern egg capsules may provide phylogenetic information.

A variety of modern invertebrates produce diapause egg capsules that form to protect the embryos from changes, in for example salinity or oxygen levels, in the environment. Copepods, tardigrades, chitons, rotifers and nematodes have egg capsules that are at least superficially closely comparable to that of some Ediacaran acritarchs. The identification of egg capsules in the fossil record is probably underestimated because of lack of diagnostic features. Cobricosphaeridium giganteum may serve as an example for the difficulty in correct identification, even at phylum level. C. giganteum was originally described as a dinoflagellate cyst (McMinn, 1991) but when living specimens of C. giganteum were incubated, the 'dinoflagellate cysts' hatched as the nauplius stage of a copepod (McMinn et al., 1992).

\section{Egg capsules of copepods or tardigrades?}

A number of copepods survive adverse environmental conditions by producing overwintering dormant (or diapause) eggs. The ability to form egg capsules is thought to be the main reason for the spring resurgence of a number of copepod species following their normal mid-winter disappearance in coastal areas. The mechanism behind the production of diapause eggs is unknown but it is probably triggered by a change in the photoperiod and temperature. It has been unclear whether dormancy in diapause eggs ensued before the embryo initiated segmentation or when it was mature and ready to hatch. Ianora \& Santella (1991) showed, however, that diapause eggs in the copepod Anomalocera patersoniwere embryos in early stages of development and that segmentation in these embryos seemed to be arrested throughout the period of dormancy. They showed that diapause eggs in $A$. patersoni undergo cleavage and that repression sets in at the 32-cell stage. Such a pattern is consistent with the presence of stages up to the 16-cell stage in the Ediacaran acritarch Tianzhushania from Doushantuo Formation (Yin et al., 2007) and may explain why later stages are not known from the fossil record.

Santella \& Ianora (1990) studied the differences between subitaneous (not dormant) and diapause eggs (with a diameter of $130-150 \mu \mathrm{m})$ in the copepod Pontella mediterranea. Using TEM they noted that smooth, subitaneous eggs, in which the plasma membrane was surrounded by a thin, electron-dense outer chorion, was strikingly different to the spiny diapause eggs, which had a thick and highly complex four-layered 
structure. This four-layered structure was described as: (1) a thick, homogeneous outer layer covered with fibrils (grey in appearance); (2) an equally thick spongy layer (dark in appearance); (3) a much thicker multilayered coat (light grey in appearance); and (4) a very thin, homogeneous inner layer covering the plasma membrane (Fig. 2C of Santella \& Ianora, 1990). They speculated that this complex wall ultrastructure served as a tough protective shell that protects the embryo against the external environment or is the sustenance of the egg during diapause. An almost identical four-layered structure was also described in the eggs of the copepod Anomalocera patersoni (Fig. 1E of Ianora \& Santella, 1991).

Willman \& Moczydłowska (2007) illustrated a four-layered wall in G. pulchrum (Fig. 6A). They suggested that the inferred
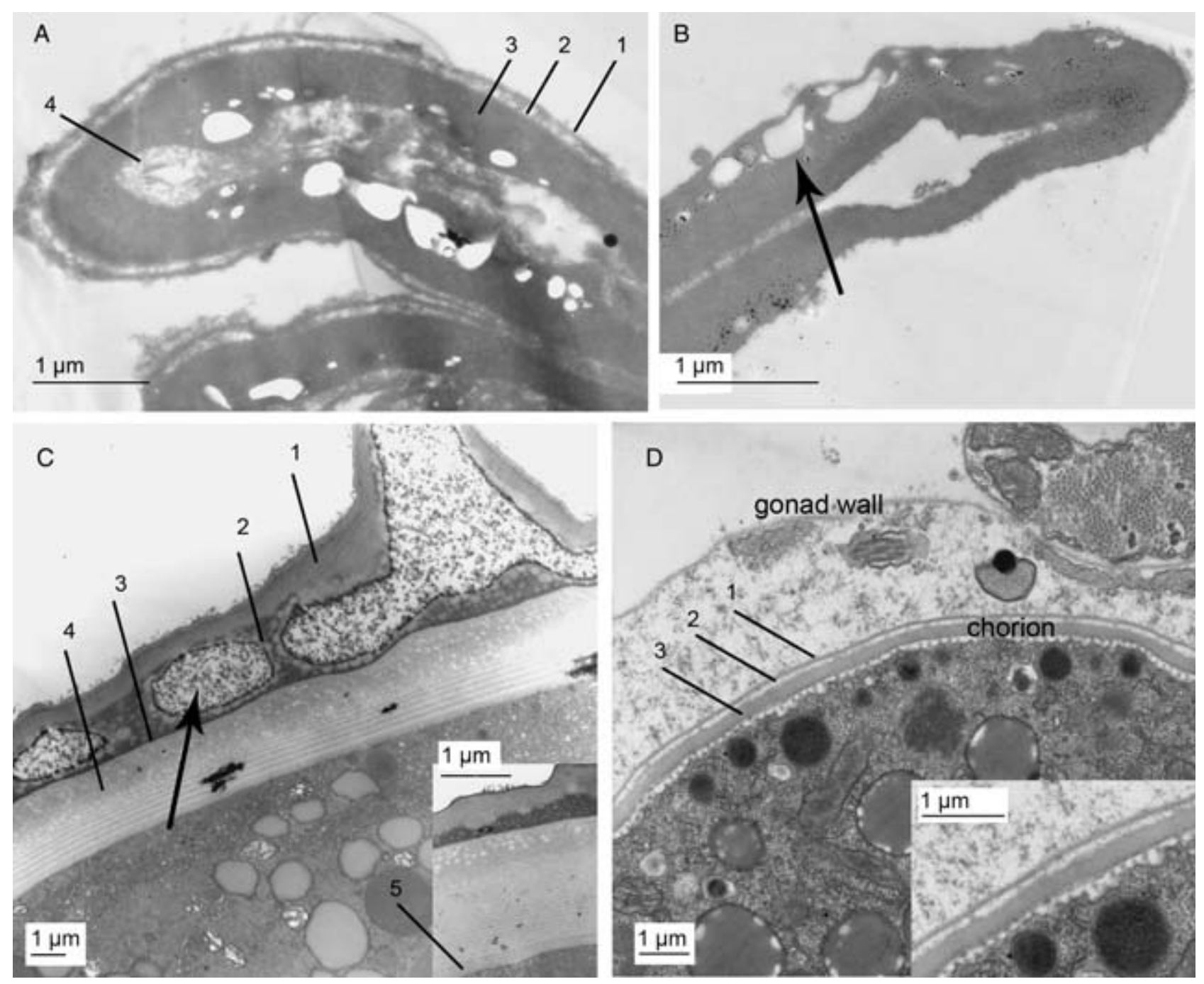

Fig. 6 Transmission electron microscopy micrographs comparing the wall ultrastructures of Gyalosphaeridium pulchrum (A-B), a fertilization envelope of a copepod egg (C) and a longitudinal section of a tardigrade gonad (D). (A) G. pulchrum, showing a four-layered wall ultrastructure, (1) an outer dark, electron-dense and homogeneous layer; (2) a light, electron-lucent and flocculent layer; (3) a thick dark, electron-dense and homogeneous layer; (4) a light, electron-lucent and homogeneous layer. Reproduced from Willman \& Moczydlowska (2007). (B) G. pulchrum, showing alveolar structure (arrow) of the outer part of the cell wall; specimen 6-A060. (C) Fertilization envelope of a copepod, Pontella mediterranea, egg. The multilayered wall contains large chambers (arrow) below the external layer, similar to those in G. pulchrum in Fig. 6B. The chambers are filled with fibrillar material. The wall consists of five layers, (1) the outer layer with fibrils and spines; (2) a second layer that probably contained pores of different electron density; (3) a thin membrane-like layer (seen in higher resolution); (4) a thick, electron-dense layer with numerous lamellae; (5) an innermost, striated layer that is not separated from the embryo (seen in inset figure). Note the large process seen partly as it extends from the wall in the upper-right corner. Courtesy of L. Santella. (D) An oocyte of the tardigrade Isohypsibius granulifer inside the gonad. The oocyte is covered by the chorion which consists of three layers: (1) the outer medium electron dense layer; (2) the middle labyrinthine layer; and (3) the inner medium electron dense layer. Inset figure shows a close-up of the three-layered chorion. Courtesy of I. Poprawa. 
chemically resistant biopolymers that formed the comparatively thick wall, together with the overall morphology implied that the microfossil was in the resting stage in the life cycle and possibly of algal origin. However, the wall ultrastructure of their G. pulchrum specimen, in terms of individual position and relative thickness of the layers, is also very similar to that of the copepod eggs described above, including the chamber-like vacuoles that are present in both G. pulchrum and P. mediterranea (arrows in Fig. 6C,D). In addition, G. pulchrum is morphologically comparable (in terms of size and process shape) to the embryo-containing Tianzhushania from South China (Yin et al., 2007), providing at least circumstantial evidence that the two large Ediacaran acanthomorphs are related and may represent preserved eggs. The fourth and rarely preserved inner layer in G. pulchrum (Fig. 2F,G) is similar to the thin-layer that surrounds the plasma membrane in the copepod eggs (Santella \& Ianora, 1990).

Other metazoan groups also produce acritarch-like egg cysts such as tardigrades. Tardigrades are a group of segmented ecdysozoans typically $100-500 \mu \mathrm{m}$ in length. They are able to survive in most environments being highly tolerant to desiccation, extreme temperatures, pressure, and even ionizing radiation by undergoing cryptobiosis (Jönsson, 2007). The fossil record of tardigrades is scarce but the oldest find is probably one of Middle Cambrian age from Siberia (Müller et al., 1995; Maas \& Waloszek, 2001). Freshwater and semiterrestrial tardigrades produce two types of egg capsules: smooth-shelled eggs laid in the exuvium, or ornamented eggs laid freely, of which the latter is only known in eutardigrades (Bertolani et al., 1996). Ramazotti \& Maucci (1983) speculated that the reason for the ornamentation was to prevent the eggs from being swept away from the substrate. Very few ultrastructural studies on the eggs are available but Poprawa (2005) describes a multilayered egg capsule (of Dactylobiotus dispar) consisting of an internal homogeneous, electron-dense layer, a middle 'labyrinthine' layer and an external layer similar to the internal layer. The ultrastructure of an oocyte from the tardigrade Isobypsibius granulifer shows a similar, threelayered ultrastructure (Fig. 6D). Again, the ultrastructure provides evidence of either convergence or a possible phylogenetic link between some organic-walled microfossils and metazoan egg capsules.

Although a metazoan affinity is possible for some of the ornamented and unornamented acritarchs, there are some difficulties that need to be addressed before making such claims. One such issue is that acritarchs that are morphologically similar to those presented here are present as early as the Mesoproterozoic, and extending the history of metazoans that far back in time is unrealistic based on current data.

\section{CONCLUSIONS}

This study of the wall ultrastructure of 12 acritarch specimens from the Ediacaran of Australia reveal vesicle walls that differ in number of individual layers, their appearance, structure and thickness. This can reflect either of two things: the specimens with different wall ultrastructures belong to different clades; or that the specimens represent various stages in their life cycles.

Based on wall ultrastructure alone, the specimens studied may be considered to represent either various types of algae in their resting/reproductive (aplanospore) stage or the egg capsules produced by a variety of metazoans and as yet ultrastructural evidence cannot distinguish between these alternatives. The complex, layered ultrastructures described here for some specimens are present in both algae and in metazoan egg capsules. In addition, the overall external morphology is also known in both algae and metazoan eggs. The different wall ultrastructures within the same taxon may represent different developmental stages. With further studies of wall ultrastructures of fossils, combined with microchemical analysis (such as micro-FTIR and micro-Raman spectroscopy and micropyrolysis gas chromatography/mass spectrometry) and with similar analyses of modern organisms, we may resolve some of the acritarch mysteries.

\section{ACKNOWLEDGEMENTS}

I would like to thank Professor Małgorzata Moczydłowska for intellectual as well as financial support throughout my study. Dr Luigia Santella (Staziona Zoologica Anton Dohrn, Naples, Italy) kindly provided pictures of copepod eggs, and Dr Izabela Poprawa (Silesian University, Katowice, Poland) was equally helpful regarding pictures of tardigrade egg cases. Anette Axén and Gary Wife at the Microscopy and Imaging unit at EBC, Uppsala University, are thanked for their expertise in preparation of the samples as well as explaining microscopic techniques. Comments by the editor, Nick Butterfield, and reviews by John Warren Huntley and an anonymous reviewer are gratefully acknowledged.

\section{REFERENCES}

Allard B, Templier J (2000) Comparison of neutral lipid profile of various trilaminar outer cell wall (TLS)-containing microalgae with emphasis on algaenan occurrence. Phytochemistry, 54, 369-380.

Amard B (1992) Ultrastructure of Chuaria (Walcott) Vidal and Ford (Acritarcha) from the Late Proterozoic Pendjari Formation, Benin and Burkina-Faso, West Africa. Precambrian Research 57, 121133.

Arouri K, Greenwood PF, Walter MR (1999) A possible chlorophycean affinity of some Neoproterozoic acritarchs. Organic Geochemistry 30, 1323-1337.

Arouri K, Greenwood PF, Walter MR (2000) Biological affinities of Neoproterozoic acritarchs from Australia: microscopic and chemical characterisation. Organic Geochemistry 31, 75-89.

Bertolani R, Rebecchi L, Calxton S (1996) Phylogenetic significance of egg shell variation in tardigrades. Zoological Journal of the Linnean Society 116, 139-148.

Brunner U, Honegger R (1985) Chemical and ultrastructural studies on the distribution of sporopolleninlike biopolymers in six genera 
of lichen phycobionts. Canadian Journal of Botany 63, 22212230.

Budd GE (2008) The earliest fossil record of the animals and its significance. Philosophical Transactions of the Royal Society B: Biological Sciences 363, 1425-1434.

Butterfield NJ (2000) Bangiomorpha pubescens n. gen., n. sp.: implications for the evolution of sex, multicellularity, and the Mesoproterozoic/Neoproterozoic radiation of eukaryotes. Paleobiology 26, 386-404.

Butterfield NJ (2005a) Probable Proterozoic fungi. Palaeobiology 31 , 165-182.

Butterfield NJ (2005b) Reconstructing a complex early Neoproterozoic eukaryote, Wynniatt Formation, arctic Canada. Lethaia 38, 155-169.

Butterfield NJ (2007) Macroevolution and macroecology through deep time. Palaeontology 50, 41-55.

Butterfield NJ, Rainbird RH (1998) Diverse organic-walled fossils, including 'possible dinoflagellates,' from the early Neoproterozoic of Arctic Canada. Geology 26, 963-966.

Calver CR, Black LP, Everard JL, Seymour DB (2004) U-Pb zircon age constraints on late Neoproterozoic glaciation in Tasmania. Geology 32, 836-896.

Colbath GK, Grenfell HR (1995) Review of biological affinities of Paleozoic acid-resistant, organic-walled eukaryotic algal microfossils (including 'acritarchs'). Review of Palaeobotany and Palynology 86, 287-314.

Condon D, Zhu M, Bowring S, Wang W, Yang A, Jin Y (2005) U-Pb ages from the Neoproterozoic Doushantuo formation, China. Science 308, 95-98.

Damiani MC, Leonardi PI, Pieroni OI, Cáceres EJ (2006) Ultrastructure of the cyst wall of Haematococcus pluvialis (Chlorophyceae): wall development and behaviour during cyst germination. Phycologia 45, 616-623.

Derenne S, Largeau C, Berkalo C, Rousseau B, Wilhelm C, Hatcher P (1992a) Non-hydrolysable macromolecular constituents from outer walls of Chlorella fusca and Nanochlorum eucaryotum. Phytochemistry 31, 1923-1929.

Derenne S, Le Berre F, Largeau C, Hatcher P, Connan J, Raynaud JF (1992b) Formation of ultralaminae in marine kerogens via selective preservation of thin resistant outer walls of microalgae. Organic Geochemistry 19, 345-350.

Derenne S, Largeau C, Berkalo C (1996) First example of an algaenan yielding an aromatic-rich pyrolysate: possible geochemical implications on marine kerogen formation. Organic Geochemistry 24, 617-627.

Evitt WR (1963) A discussion and proposals concerning fossil dinoflagellates, hystrichospheres and acritarchs. Proceedings of the National Academy of Sciences of the USA 49, 158-164, 298-302.

Gelin F, Volkman JK, Largeau C, Derenne S, Sinninghe Damsté JS, De Leeuw JW (1999) Distribution of aliphatic, nonhydrolyzable biopolymers in marine microalgae. Organic Geochemistry 30, 147-159.

Grey K (1999) A modified palynological preparation technique for the extraction of large Neoproterozoic acanthomorph acritarchs and other acid insoluble microfossils. Geological Survey of Western Australia Record 10, 23 pp.

Grey K (2005) Ediacaran palynology of Australia. Memoir of the Association of Australasian Palacontologists 31, $439 \mathrm{pp}$.

Grey K, Calver CR (2007) Correlating the ediacaran of Australia. Geological Society, London, Special Publications, 286, 115-135.

Hagen C, Siegmund S, Braune W (2002) Ultrastructural and chemical changes in the cell wall of Haematococcus pluvialis (Volvocales, Chlorophyta) during aplanospore formation. European Journal of Phycology 37, 217-226.

Hill AC, Grey K, Gostin VA, Webster LJ (2004) New records of Late
Neoproterozoic Acraman ejecta in the Officer Basin. Australian Journal of Earth Sciences 51, 47-51.

Hill AC, Haines PW, Grey K, Willman S (2007) New records of Ediacaran Acraman ejecta in drillholes from the Stuart Shelf and Officer Basin, South Australia. Meteoritics and Planetary Science 42, 1883-1891.

Huntley JW, Xiao S, Kowalewski M (2006) 1.3 billion years of acritarch history: an empirical morphospace approach. Precambrian Research 144, 52-68.

Ianora A, Santella L (1991) Diapause embryos in the neustonic copepod Anomalocera patersoni. Marine Biology 108, 387-394.

Javaux EJ, Marshal CP (2006) A new approach in deciphering early protist palaeobiology and evolution: combined microscopy and microchemistry of single Proterozoic acritarchs. Review of Palaeobotany and Palynology 139, 1-15.

Javaux EJ, Knoll AH, Walter MR (2004) TEM evidence for eukaryotic diversity in mid-Proterozoic oceans. Geobiology 2 , $121-132$.

Jönsson KI (2007) Tardigrades as a potential model organism in space research. Astrobiology 7, 757-766.

Jux U (1968) Über den Feinbau der Wandung bei Tasmanites Newton. Palaeontographica Abt. B 124, 112-124.

Jux U (1969a) Über den Feinbau der Zystenwandung von Pachysphaera marshalliae Parke, 1966. Palaeontographica Abt. B $125,104-111$.

Jux U (1969b) Über den Feinbau der Zystenwandung von Halosphaera Schmitz, 1878. Palaeontographica Abt. B 128, 48-55

Jux U (1971) Über den Feinbau der Wandungen einiger paläozischer Baltisphaeidiacean. Palaeontographica Abt. B 136, 115-128.

Jux U (1977) Über die wandstrukturen sphaeromorpher acritarchen: Tasmanites Newton, ZTapajonites Sommer \& Van Boekel, ZChuaria Walcott. Palaeontographica Abt. B 160, 1-16.

Kjellström G (1968) Remarks on the chemistry and ultrastructure of the cell wall of some Palaeozoic leiospheres. Geologiska Föreningens I Stockholm Förhandlingar 90, 118-221.

Knoll AH, Javaux EJ, Hewitt D, Cohen P (2006a) Eukaryotic organisms in Proterozoic oceans. Philosophical Transactions of the Royal Society B: Biological Sciences 361, 1023-1038.

Knoll AH, Walter MR, Narbonne GM, Christie-Blick N (2006b) The ediacaran period: a new edition to the geologic time scale. Lethaia $39,13-30$

Knoll AH, Summons RE, Waldbauer JR, Zumberge JE (2007) The geological consequences of primary producers in the oceans. In Evolution of Primary Producers in the Sea (eds Falkowski PG, Knoll AH). Elsevier, Boston, Massachusetts, pp. 133-163.

Maas A, Waloszek D (2001) Cambrian derivatives of the early arthropod stem lineage penastomids, tardigrades and lobopodians - an 'Orsten' perspective. Zoologischer Anzeiger 240, 451-459.

Marshall CP, Javaux EJ, Knoll AH, Walter MR (2005) Combined micro-Fourier transform infrared (FTIR) spectroscopy and microRaman spectroscopy of Proterozoic acritarchs: a new approach to Palaeobiology. Precambrian Research 138, 208-224.

Marshall CP, Carter EA, Leuko S, Javaux EJ (2006) Vibrational spectroscopy of extant and fossil microbes: relevance for the astrobiological exploration of Mars. Vibrational Spectroscopy 41, 182-189.

Martin F, Kjellström G (1973) Ultrastructural study of some Ordovician acritarchs from Gotland, Sweden. Neues Jahrbuch für Geologie und Paläontologie Monatshefte 1, 44-54.

McMinn A (1991) Recent dinoflagellate cysts from estuaries on the central coast of New South Wales, Australia. Micropaleontology 37, 269-287.

McMinn A, Bolch C, Hallegraeff G (1992) Cobricosphaeridium harland and sarjeant: dinoflagellate cyst or copepod egg? Micropaleontology 38, 315-316. 
Meng F, Zhou C, Yin L, Chen Z, Yuan X (2005) The oldest known dinoflagellates: morphological and molecular evidence from Mesoproterozoic rocks at Yongji, Shanxi Province. Chinese Science Bulletin 50, 1230-1234.

Moldowan JM, Talyzina NM (1998) Biogeochemical evidence for dinoflagellates ancestors in the early Cambrian. Science 281, $1168-1170$.

Moldowan JM, Dahl J, Jacobson SR, Huizinga BJ, Fago FJ, Shetty R, Watt DS, Peters KE (1996) Chemostratigraphic reconstruction of biofacies; molecular evidence linking cyst-forming dinoflagellates with pre-Triassic ancestors. Geology 24, 159-162.

Müller KJ, Walossek D, Zakharov A (1995) 'Orsten' type phosphatized soft-integument preservation and a new record from the Middle Cambrian Kuonamka Formation in Siberia. Neues Jahrbuch für Geologie und Paläontologie, Abh. 191, 107-118.

Peat CJ (1981) Comparative light microscopy, scanning electron microscopy and transmission electron microscopy of selected organic walled microfossils. Journal of Microscopy 122, 287-294.

Poprawa I (2005) The structure and the formation of egg shells in the pathenogenetic species Dactylobiotus dispar Murray, 1907 (Tardigrada: Eutardigrada). Folia Biologica 53, 173-177.

Ramazotti G, Maucci W (1983) Il Phylum Tardigrada (III edizione riveduta e aggiornata). Memorie dell' Istituto Italiano di Idrobiologia 41, 1-1012.

Santella L, Ianora A (1990) Subitaneous and diapause eggs in Mediterranean populations of Pontella mediterranea (Copepoda: Calanoida): a morphological study. Marine Biology 105, 83-90.

Strother PK (1996) Chapter 5, Acritarchs. In Palynology: Principles and Applications, Vol. 1 (eds Jansonius J, McGregor DC). American association of stratigraphic palynologists Foundation. Publishers Press, Salt Lake City, Utah, pp. 81-106.

Talyzina NM (2000) Ultrastructure and morphology of Chuaria circularis (Walcott 1899) Vidal and Ford 1985 from the Neoproterozoic Visingsö Group Sweden. Precambrian Research 102, 123-134.

Talyzina NM, Moczydłowska M (2000) Morphological and ultrastructural studies of some acritarchs from the Lower Cambrian
Lükati Formation, Estonia. Review of Palaeobotany and Palynology $112,1-21$

Tappan H (1980) The Palaeobiology of Plant Protists. Freeman, San Francisco, California.

Van Waveren IM, Marcus NH (1993) Chapter 4: morphology of recent copepod egg envelopes from Turkey Point (Gulf of Mexico) and their implications for acritarch affinity. Special Papers in Paleontology 48, 123-141.

Wall D (1962) Evidence from recent plankton regarding the biological affinities of Tasmanites Newton 1875 and Leiosphaeridia Eisenack 1958. Geological Magazine 99, 353-362.

Willman S, Moczydłowska M (2007) Wall ultrastructure of an Ediacaran acritarch from the Officer Basin, Australia. Lethaia 40, $111-123$.

Willman S, Moczydłowska M (2008) Ediacaran acritarch biota from the Giles 1 drillhole, Officer Basin, Australia, and its potential for biostratigraphic correlation. Precambrian Research 162, 498530.

Willman S, Moczydłowska M, Grey K (2006) Neoproterozoic (Ediacaran) diversification of acritarchs - a new record from the Murnaroo 1 drillcore, eastern Officer Basin, Australia. Review of Palaeobotany and Palynology 139, 17-39.

Xiao S, Knoll AH (2000) Phosphatized animal embryos from the Neoproterozoic Doushantuo Formation at Weng'an, Guzhou, South China. Journal of Paleontology 74, 767-788.

Xiao S, Zhang Y, Knoll AH (1998) Three-dimensional preservation of algae and animal embryos in a Neoproterozoic phosphorite. Nature 391, 553-558.

Yin C, Bengtson S, Yue Z (2004) Silicified and phosphatized Tianzhushania, spheroidal microfossils of possible animal origin from the Neoproterozoic of South China. Acta Palaeontologica Polonica 49, 1-12.

Yin L, Zhu M, Knoll AH, Yuan X, Zhang J, Hu J (2007) Doushantuo embryos preserved inside diapause eggs. Nature 446, 661-663.

Zang W-L (1995) Neoproterozoic depositional sequences and tectonics, eastern Officer Basin, South Australia. South Australia. Department of Mines and Energy. Report Book, p. 21. 